\title{
Effects of low-dose methotrexate in spinal cord injury in rats
}

\author{
Düşük doz metotreksatın sıçanlarda omurilik yaralanmasına etkileri
}

\author{
Bülent BAKAR, ${ }^{1}$ Emine Arzu KÖSE, ${ }^{2}$ Şebnem KUPANA AYVA, ${ }^{3}$ Bahram SARKARATİ, ${ }^{4}$ \\ Mustafa Ömür KASIMCAN, ${ }^{1}$ Kamer KILINÇ ${ }^{4}$
}

\section{BACKGROUND}

This study was designed to evaluate the possible protective effects of low-dose methotrexate in the spinal cord injury $(\mathrm{SCI})$ in rats.

\section{METHODS}

Thirty-seven Wistar albino rats were used in the present study. Except for the animals of the Sham group, all animals were divided into two main groups, which were used in acute and subacute stage investigations. Then, thoracal laminectomy was performed, and except for the Sham group, SCI was induced using a temporary aneurysm clip. After clip compression, the experimental material (methotrexate or methylprednisolone) was administered intraperitoneally, except in the Sham and Control groups. Then, the spinal cords were removed to evaluate the SCI histopathologically and biochemically at the scheduled date.

\section{RESULTS}

Neither experimental material was shown to reduce the histopathological grade in either stage of SCI. Low-dose methotrexate was shown to decrease lipid peroxidation levels only in the subacute stage of SCI. However, methylprednisolone and low-dose methotrexate could not decrease or block myeloperoxidase enzyme activation in either stage of SCI.

\section{CONCLUSION}

Low-dose methotrexate was effective in reducing the lipid peroxidation levels in the subacute stage of SCI, although histopathological evaluation results and myeloperoxidase levels of all groups did not support this finding at either stage.

Key Words: Low-dose methotrexate; methylprednisolone; spinal cord injury.

\begin{abstract}
$\boldsymbol{A M A C}$
Bu çalışma, düşük doz metotreksatın sıçanlarda oluşturulan omurilik yaralanması üzerindeki olası koruyucu etkilerini incelemek amaciyla yapıldı.
\end{abstract}

\section{GEREC VE YÖNTEM}

Otuz yedi adet Wistar albino sıçan üzerinde torakal laminektomi uygulandı ve sham grubu hariç tüm hayvanlarda geçici anevrizma klibi kullanılarak omurilik travması oluşturuldu. Akut ve subakut dönemde travmanın etkilerini incelemek amacıyla sham grubundaki hayvanlar dışındaki diğer hayvanlar iki ana gruba ayrıldı. Travma sonrası sham ve kontrol grupları hariç tüm hayvanlara ilgili deneysel ilaç (metotreksat veya metilprednisolon) periton içine verildi. Hayvanların omurilikleri travmanın histolojik ve biyokimyasal etkilerini incelemek amacıyla çıkarıldı.

\section{BULGULAR}

Her iki deneysel materyalin de omurilik travmasının herhangi bir evresinde histopatalojik düzeyde belirgin düzeltici etkisinin olmadığı gözlendi. Travmanın gözlenen subakut evresinde metotreksatın lipit peroksidasyon düzeyini azaltmada metilprednisolona göre belirgin üstünlüğe sahip olduğu saptand1. Ancak, akut ve subakut dönemlerde her iki ajanın da miyeloperoksidasyon düzeyleri üzerinde etkili olmadığı saptandı.

\section{SONUÇ}

Düşük doz metotreksatın sıçanlarda oluşturulan omurilik yaralanmasının subakut döneminde gelişen lipit peroksidasyon düzeyleri üzerinde azaltıcı etkisi olduğu ancak miyeloperoksidasyon aktiviteleri ve histopatolojik evre bulguları üzerinde etkili olmadığı saptanmıştır.

Anahtar Sözcükler: Düşük doz metotreksat; metilprednisolon; omurilik yaralanmas1.
Departments of ${ }^{1}$ Neurosurgery, ${ }^{2}$ Anaestesiology and Reanimation, Kirikkale University Faculty of Medicine, Kirikkale; ${ }^{3}$ Department of Pathology, Baskent University Faculty of Medicine, Ankara; ${ }^{4}$ Department of Biochemistry, Hacettepe University Faculty of Medicine, Ankara, Turkey.
Kırkkkale Üniversitesi Tıp Fakültesi, ${ }^{1}$ Nörosirürji Anabilim Dalı, ${ }^{2}$ Anesteziyoloji ve Reanimasyon Anabilim Dalı, Kırikkale; ${ }^{3}$ Başkent Üniversitesi Tıp Fakültesi, Patoloji Anabilim Dalı, Ankara; ${ }^{4}$ Hacettepe Üniversitesi Tıp Fakültesi, Biyokimya Anabilim Dalı, Ankara.

Correspondence (Illetişim): Bülent Bakar, M.D. Kırıkkale Ünniversitesi Tıp Fakültesi, Fabrikalar Mah., Sağlık Cad. Sağlık Sok., 71100 Kırıkale, Turkey. Tel: +90 - 318 - 2252485 e-mail (e-posta): bulentbanrs@yahoo.com 
Many reports in the literature have explained that some biochemical and inflammatory reactions, called secondary cord damage, develop due to the primary effects of spinal cord injury (SCI) and promote the occurrence of edema and hemorrhage during the acute stage. This response includes vascular permeability, excessive release of glutamate and aspartate, intracellular calcium overload, activation of the arachidonic acid cascade, induction of lipid peroxidation (LPO), and activation of resident glial cells. These events precede infiltration by large numbers of inflammatory cells such as neutrophils and macrophages, which can destroy the neurons and sheath of axons by releasing excessive amount of cytokines, cytotoxic substances (such as superoxide anion, chloride anion, hydroxyl radicals), and tumor necrosis factor-alpha (TNF- $\alpha) \cdot .^{[1,2]}$ Additionally, microglia can also produce superoxide and nitric oxide when they are exposed to oxidative stress. Today, it has been accepted that the critical step for the acute treatment of SCI is to reduce these cytokines by blocking the infiltration of these inflammatory cells into the injured spinal cord, as it will reduce secondary cord damage. ${ }^{[1]}$

Recently, low-dose methotrexate (MTX) has become the mainstay in the treatment of some inflammatory diseases such as rheumatoid arthritis. ${ }^{[3,4]}$ Chronstein et al. ${ }^{[3]}$ showed that low-dose MTX can inhibit both proliferation of lymphocytes in an inflammatory exudate and reduce the destructive capacity of the leukocytes that do arrive at the inflammation site. Although its exact mechanism of action has not been clarified yet, low-dose MTX promotes extracellular adenosine accumulation at the inflammation sites. Adenosine, which interacts with its receptors (adenosine A2 receptor) in stimulated inflammatory cells, inhibits some cytokines such as interleukin (IL)-1, IL-4, IL13, interferon (IFN)-gamma, leukotrienes released by neutrophils (but not macrophages), and granulocyte macrophage colony-stimulating factor. Adenosine also inhibits the superoxide, nitric oxide and TNF- $\alpha$ released by monocytes and macrophages. ${ }^{[5]}$ Additionally, adenosine has cytoprotective effects resulting from inhibition of the toxic oxygen metabolites that are generated from the adhesion of stimulated neutrophils to the endothelium. ${ }^{[3,6]}$

Based on all these results, this preliminary study was designed to investigate the possible neuroprotective effects of low-dose MTX in the secondary damage of SCI in rats.

\section{MATERIALS AND METHODS}

\section{Materials}

This experimental study was performed in accordance with the guidelines for the use of laboratory animal subjects in a research setting by the Ethical Com- mittee of Kırıkkale University (Number: 11/204).

Methotrexate (MTX; Methotrexate DBL, Hospira Australia PYY Ltd., Mulgrave, Victoria, Australia) and methylprednisolone (MP; Depo-Medrol ${ }^{\circledR}$, Pharmacia \& Upjohn Company, Kalamazoo, USA) were used in this study. The density of Methotrexate DBL is $25 \mathrm{mg} / \mathrm{ml}$, and the intraperitoneal LD50 of Methotrexate DBL is $6 \mathrm{mg} / \mathrm{kg}$ in rats. The density of DepoMedrol $^{\circledR}$ is $40 \mathrm{mg} / \mathrm{ml}$, and the intraperitoneal LD50 of Depo-Medrol ${ }^{\circledR}$ is $1 \mathrm{~g} / \mathrm{kg}$ in rats.

Thirty-seven Wistar albino rats weighing 250-350 $\mathrm{g}$ were used in this study. Except for the animals of the Sham group $(n=5)$, all animals were divided into two main groups randomly, which were used in the acute ( 72 hours after SCI) and subacute (5 days after SCI) stage investigations of SCI. Then, each main group was also divided into three subgroups as described below. Neither clip compression nor experimental material administration was performed to the animals of the Sham group.

The acute stage groups were divided into three subgroups randomly as follows:

- Control-A group (no chemical material was infused; $\mathrm{n}=5$ )

- MP-A group (methylprednisolone was infused intraperitoneally; $\mathrm{n}=5$ )

- MTX-A group (low-dose methotrexate was infused intraperitoneally; $n=7$ )

The subacute stage groups were also divided into three subgroups randomly as follows:

- Control-C group (no chemical material was infused; $\mathrm{n}=5$ )

- MP-C group (methylprednisolone was infused intraperitoneally; $\mathrm{n}=5$ )

- MTX-C group (low-dose methotrexate was infused intraperitoneally; $\mathrm{n}=5$ )

Anesthesia was performed with intramuscular administration of ketamine $\mathrm{HCl}$ (Ketalar ${ }^{\circledR}$; Pfizer Inc, USA) and xylazine $\mathrm{HCl}\left(\right.$ Rompun $^{\circledR} 2 \%$; Bayer HealthCare AG, Germany).

\section{Methods}

The spinal cord contusion was performed using a clip compression technique described by Rivlin and Tator ${ }^{[7]}$ All animals were sedated with intramuscular $40 \mathrm{mg} / \mathrm{kg}$ ketamine $\mathrm{HCl}$ and $5 \mathrm{mg} / \mathrm{kg}$ xylazine $\mathrm{HCl}$ on spontaneous respiration at room temperature. A dorsal laminectomy at thoracal 9-10 level was performed to all animals, and the dura mater was left intact. The spinal cord was exposed, and except for the Sham group, SCI was induced using a temporary 

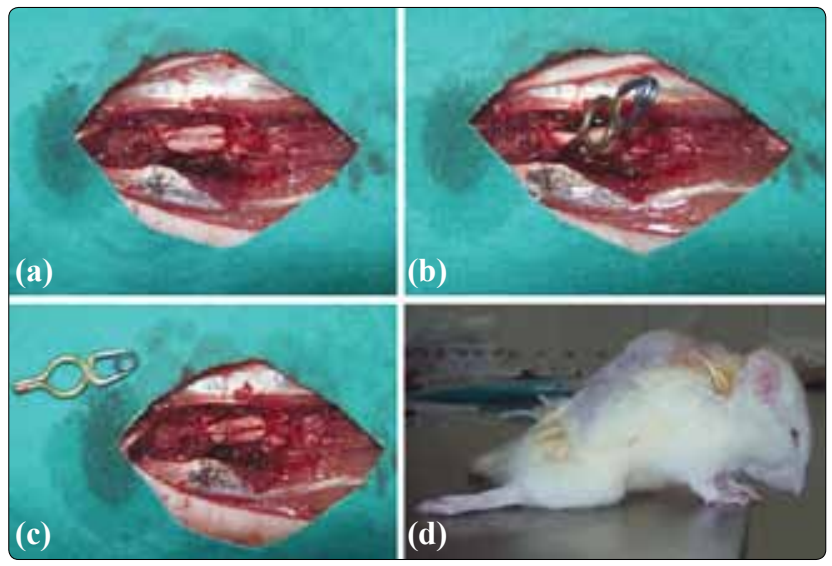

Fig. 1. (a) A dorsal laminectomy at thoracal 9-10 level was performed, and $(\mathbf{b}, \mathbf{c})$ traumatic SCI was induced by using a temporary aneurysm clip applied for $60 \mathrm{sec}-$ onds (d) that resulted in hind limb locomotor deficit. (Color figure can be viewed in the online issue, which is available at www.tjtes.org).

aneurysm clip (Mizuho ${ }^{\circledR}$ Aneurysm Clip, Mizuho, Japan) for 60 seconds (Fig. 1). Four hours after the clip compression, except rats of the Sham, Control-A and Control-C groups, the experimental material $(0.05 \mathrm{mg} /$ $\mathrm{kg}$ MTX or $30 \mathrm{mg} / \mathrm{kg} \mathrm{MP)} \mathrm{was} \mathrm{slowly} \mathrm{administered}$ (within 5 seconds) through the intraperitoneal route using a $22 \mathrm{G}$ needle. After this procedure, all rats were removed from sedation spontaneously under the blanket. Hind limb locomotor deficit resulting from SCI was observed in all rats except the Sham group animals (Fig. 1). Seventy-two hours later, the animals of the Sham, Control-A, MP-A, and MTX-A groups and 5 days later the animals of the Control-C, MP-C, and MTX-C groups were re-sedated with intramuscular 40 $\mathrm{mg} / \mathrm{kg}$ ketamine $\mathrm{HCl}$ and $5 \mathrm{mg} / \mathrm{kg}$ xylazine $\mathrm{HCl}$. After sedation, rats were sacrificed using cardiac air embolization. Then, the first dorsal incision of the animals was re-opened, and the spinal cords were removed totally from the T8 to the conus medullaris level. The sample tissues were immediately harvested for future biochemical and histopathological examinations, and divided into two parts. The proximal part of the spinal cord, to which clip compression was applied, was stored in $10 \%$ buffered formaldehyde solution at room temperature for histopathological examination. The remaining distal part of the spinal cord was stored at $-30^{\circ} \mathrm{C}$ in dry air for biochemical examination.

\section{Specimen analysis}

For histopathological examination, all tissue samples were fixed in $10 \%$ buffered formaldehyde and processed according to routine light microscopic tissue processing technique. Serial sections of $5 \mu \mathrm{m}$ stained with hematoxylin-eosin were examined and photographed with a light microscope (Leica ${ }^{\circledR}$ Microsystems, Wetzlar $\mathrm{GmbH}$ ). Each section was evaluated by an experienced pathologist blinded to the groups and test materials. For histopathological evaluation of the SCI, a grading system described by Black et al. ${ }^{[8]}$ was applied to all specimens as follows (Fig. 2):

- grade 0: no destruction in the spinal cord tissue histopathologically.

- grade I: mild neural tissue destruction and polymorphonuclear cell infiltration without neuronal cell loss; the posterior column of the spinal cord was affected.

- grade II: moderate neural tissue destruction and

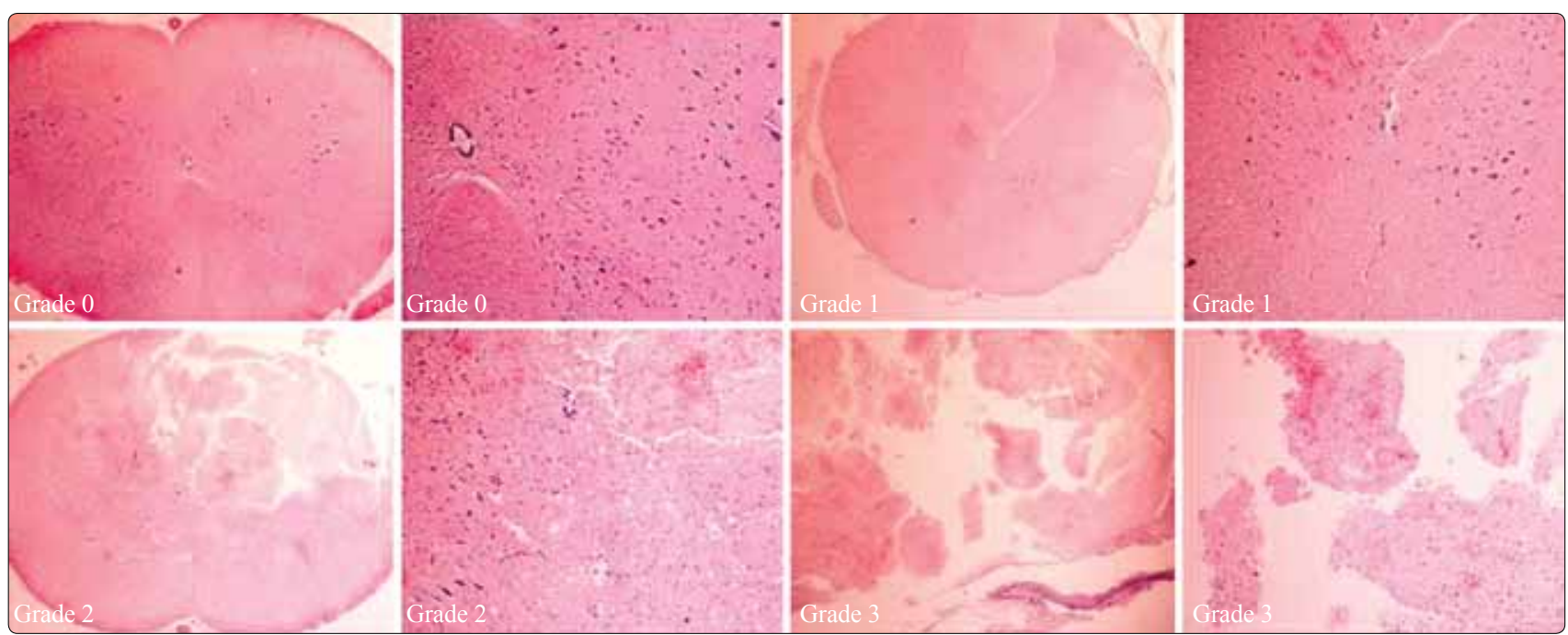

Fig. 2. Histopathological grades involved Grade 0: no neural tissue destruction; Grade I: mild neural tissue destruction and polymorphonuclear cell infiltration without neuronal cell loss - the posterior column of the spinal cord was affected; Grade II: moderate neural tissue destruction and macrophage and/or histiocyte infiltration with white matter loss and central cavitation; and Grade III: severe neural tissue destruction with white and gray matter cystic necrosis and gliosis (hematoxylineosin, original magnification $\mathrm{x} 100$, and $\mathrm{x} 400$ ). (Color figure can be viewed in the online issue, which is available at www.tjtes.org). 
Table 1. Descriptive table of the histopathological grades

\begin{tabular}{lccccc}
\hline & \multicolumn{4}{c}{ Histopathological grades } & Median value \\
\cline { 2 - 5 } Groups & Grade 0 & Grade 1 & Grade 2 & Grade 3 & \\
\hline Sham & 4 & 1 & - & - & 0 \\
Control-A & - & - & 4 & 1 & 2 \\
MP-A & - & - & 2 & 3 & 3 \\
MTX-A & - & - & 6 & 1 & 2 \\
Control-C & - & - & 3 & 2 & 2 \\
MP-C & - & 1 & 4 & - & 2 \\
MTX-C & - & - & 4 & 1 & 2 \\
\hline
\end{tabular}

MP: Methylprednisolone; MTX: Methotrexate.

macrophage and/or histiocyte infiltration with white matter loss and central cavitation.

- grade III: severe neural tissue destruction with white and gray matter cystic necrosis and gliosis. ${ }^{[8]}$

Biochemical determinations were carried out by two biochemists blinded to the animal groups and test materials. Frozen tissue samples were weighed and homogenized in 1:10 (w:v) potassium phosphate buffer (50 mM, pH: 7.4) using a dounce homogenizer. Thiobarbituric acid reactive substances (TBARS) were measured as an index of LPO by the method of Mihara et al. ${ }^{[9,10]}$ Tissue levels of lipid peroxides (as TBARS) were calculated as nanomole per gram wet tissue. Tissue-associated myeloperoxidation (MPO) activity was measured by the modified method of Suzuki et al. ${ }^{[11,12]}$ Tissue homogenate $(0.5 \mathrm{ml})$ was centrifuged at $10.000 \mathrm{xg}$ for 5 minutes ( $\mathrm{min}$ ), and the pellet was resuspended in equal volume $(0.5 \mathrm{ml})$ of $50 \mathrm{mM}$ phosphate buffer $(\mathrm{pH}=6.0)$ containing $0.5 \%$ hexadecyltrimethyl ammonium bromide (HETAB) and $5 \mathrm{mM}$ EDTA. The resulting suspension was centrifuged at $5.000 \mathrm{xg}$ for 2 min and the supernatant was used for the activity measurement. The MPO activity was measured in a final volume of $1 \mathrm{ml}$ containing $80 \mathrm{mM}$ phosphate buffer $(\mathrm{pH}=5.4), 0.5 \%$ HETAB, $1.6 \mathrm{mM}$ synthetic substrate tetramethylbenzidine (TMB) initially dissolved in dimethylformamide, $2 \mathrm{mM} \mathrm{H}_{2} \mathrm{O}_{2}$, and the sample. The reaction was started at $37^{\circ} \mathrm{C}$ with the addition of $\mathrm{H}_{2} \mathrm{O}_{2}$. The initial rate of MPO-catalyzed TMB oxidation was followed by recording the increase of absorbance at $655 \mathrm{~nm}$ (Shimadzu ${ }^{\circledR}$ UV-120-02 spectrophotometry). The MPO activity was expressed as the amount of the enzyme producing one absorbance change per minute under assay conditions. Tissue-associated MPO activity was calculated as units per gram of wet tissue.

\section{Statistical analysis}

Histopathological grades that were not normally distributed and the variation that was not homogeneous between all groups were statistically analyzed by the chi-square test. To determine the statistical differences between the groups (post hoc evaluation), the chisquare test was performed to all grade results. $P$ values lower than 0.05 were considered to be significant.

Tissue LPO and MPO levels were normally distributed and the variation was homogeneous between all
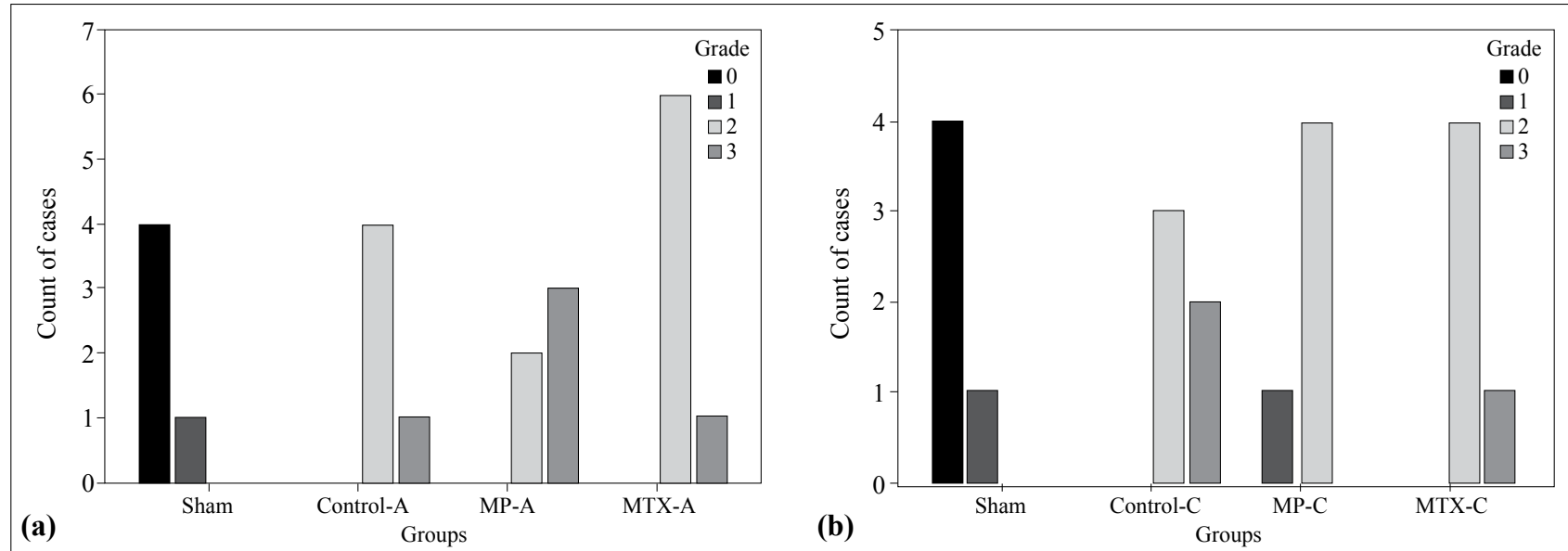

Fig. 3. The variation of the histopathological grades in (a) acute and (b) subacute stages of SCI (MP: Methylprednisolone; MTX: Methotrexate). 
groups. Therefore, they were statistically analyzed by the one-way analysis of variance (one-way ANOVA) test. Furthermore, to determine the statistical differences between the groups, post hoc evaluation (oneway ANOVA-Tukey multiple comparisons test and Bonferroni multiple comparisons test) was performed to all biochemical results. P values lower than 0.0083 were considered to be significant. ${ }^{[13]}$

\section{RESULTS}

\section{Light Microscopy}

Four rats of the Sham group had grade 0 , and 1 rat had grade I degeneration.

In the acute stage, 4 rats of the Control-A group had grade II, and 1 rat had grade III degeneration. Two rats of the MP-A group had grade II and 3 rats had grade III degeneration. In the MTX-A group, 6 rats had grade II, and 1 rat had grade III degeneration (Table 1, Fig. 3). Except for 3 animals of the ControlA group, which had mild acute inflammatory reaction, no inflammatory reaction was observed in the remaining groups.

In the subacute stage, 3 rats of the Control-C group had grade II, and 2 rats had grade III degeneration. Three of them had mild chronic inflammatory reaction (glial histiocyte infiltration). One rat of the MP-C group showed grade I, and the other 4 rats showed grade II degeneration. Three of them had moderate inflammatory reaction developed due to neutrophils. In the MTX-C group, 4 rats had grade II and 1 rat had grade III degeneration (Table 1, Fig. 3). In 4 of them, severe inflammatory reaction developed due to mixed type inflammatory cell infiltration (macrophages and histiocytes).

The variation of the median values of the histopathological grades was statistically significant when the acute and subacute stages of all groups were compared using the chi-square test $\left(X^{2}=29.270, p<0.001\right)$ (Table 2). The post hoc evaluation results obtained from the chi-square test showed that there were significant differences between the Sham/Control-A (degrees of freedom $[\mathrm{df}]=3, \mathrm{p}=0.019$ ), Sham/ControlC $(\mathrm{df}=3, \mathrm{p}=0.019)$, Sham/MP-A $(\mathrm{df}=3, \mathrm{p}=0.019)$, Sham/MP-C $(\mathrm{df}=3, \mathrm{p}=0.018)$, Sham/MTX-A $(\mathrm{df}=3$, $\mathrm{p}=0.007)$, and Sham/MTX-C groups $(\mathrm{df}=3, \mathrm{p}=0.019)$ (Table 3, Fig. 3).

\section{Biochemical analysis}

\section{The evaluation of LPO levels}

The variation of the mean values of the LPO levels was statistically significant $(\mathrm{p}=0.001 ; \mathrm{F}=5.119)$ using the one-way ANOVA test (Tables 4, 5). The post hoc evaluation results of the LPO levels obtained using the one-way ANOVA-Tukey multiple comparisons test
Table 2. This table demonstrates that there was a statistically significant difference between all groups described in the text when comparing their histopathological grades

\begin{tabular}{lccc}
\hline & Chi-square & df & $p$ \\
\hline Histopathological grade & 29.270 & 3 & $<0.001$ \\
\hline
\end{tabular}

chi-square test, $\mathrm{p}<0.05$. df: Degrees of freedom.

Table 3. The post hoc evaluation shows that neither experimental material could reduce the histopathological grade in either stage of spinal cord injury

\begin{tabular}{lcc}
\hline Groups & $\mathrm{df}$ & $\mathrm{p}$ \\
\hline Sham/Control-A & 3 & $0.019^{*}$ \\
Sham/MP-A & 3 & $0.019^{*}$ \\
Sham/MTX-A & 3 & $0.007^{*}$ \\
Control-A/MP-A & 1 & 0.262 \\
Control-A/MTX-A & 1 & 0.682 \\
MP-A/MTX-A & 1 & 0.152 \\
Sham/Control-C & 3 & $0.019^{*}$ \\
Sham/MP-C & 2 & $0.018^{*}$ \\
Sham/MTX-C & 3 & $0.019^{*}$ \\
Control-C/MP-C & 1 & 0.095 \\
Control-C/MTX-C & 1 & 0.500 \\
MP-C/MTX-C & 1 & 0.180 \\
\hline
\end{tabular}

chi-square test, $\mathrm{p}<0.05$. MP: Methylprednisolone; MTX: Methotrexate; df: Degrees of freedom.

demonstrated that there were significant differences between the Control-C/MTX-C groups $(\mathrm{p}=0.007)(\mathrm{Ta}-$ ble 6, Fig. 4).

\section{The evaluation of MPO levels}

The variation of the mean values of the MPO levels was statistically significant obtained using the one-way ANOVA test $(\mathrm{F}=7.766, \mathrm{p}<0.001)$ (Tables 4,5$)$. The post hoc evaluation results of the MPO levels showed that there were significant differences between Sham/ Control-A ( $p=0.001)$, Sham/Control-C $(p=0.005)$, and Sham/MP-C groups $(\mathrm{p}<0.001)$ (Table 7, Fig. 5).

\section{DISCUSSION}

\section{Evaluation of the histopathological results}

Acute SCI is followed by progressive secondary procedures of tissue destruction arising from the inflammatory response. This inflammatory response is biphasic. The first phase involves lysosomal degradation and free radical formation, which have a role in chemotaxis of the neutrophils and tissue macrophages. Neutrophil infiltration into the injured spinal cord tissue occurs in approximately 6 hours. It peaks in 24 to 48 hours and may persist during the first week. ${ }^{[14,15]}$ The 
Table 4. Descriptive table of the mean lipid peroxidation and myeloperoxidation levels

\begin{tabular}{lccccc}
\hline Groups & Variable & Minimum & Maximum & Mean & SD \\
\hline Sham & LPO & 37.23 & 56.70 & 48.32 & 7.46 \\
\multirow{3}{*}{ Control-A } & MPO & 0.00 & 4.07 & 1.43 & 1.57 \\
& LPO & 59.65 & 79.96 & 68.54 & 7.46 \\
MP-A & MPO & 16.39 & 18.59 & 17.53 & 0.84 \\
& LPO & 44.42 & 68.11 & 56.10 & 9.22 \\
MTX-A & MPO & 5.06 & 18.26 & 10.03 & 5.80 \\
& LPO & 37.23 & 68.11 & 51.37 & 11.68 \\
Control-C & MPO & 0.00 & 16.61 & 9.37 & 6.14 \\
& LPO & 64.73 & 71.92 & 68.28 & 2.625 \\
MP-C & MPO & 14.52 & 16.17 & 15.16 & 0.64 \\
& LPO & 38.08 & 76.58 & 55.42 & 13.76 \\
MTX-C & MPO & 5.61 & 34.98 & 22.11 & 10.57 \\
& LPO & 39.77 & 52.04 & 45.44 & 4.90 \\
\hline
\end{tabular}

LPO: Lipid peroxidation; MP: Methylprednisolone; MPO: Myeloperoxidation; MTX: Methotrexate; SD: Standard deviation.

second phase includes damaging of the neural tissue by macrophages, microglia and histiocytes. ${ }^{[16]}$ Clinical studies have suggested that pharmacologic therapies may be effective in minimizing the observed outcomes after SCI. Although many pharmacological agents have been described as a potential effective agent to improve the secondary cord damage caused by SCI, steroids are still accepted worldwide as a single option for urgent treatment of SCI. Steroids have antioxidant, anti-inflammatory, and cell membrane stabilizing properties, and may be beneficial in a time- and dose-dependent manner. They have also anti-edema activities. ${ }^{[17]}$

In the present study, almost all groups had grade II degeneration except those of the Sham and MP-A

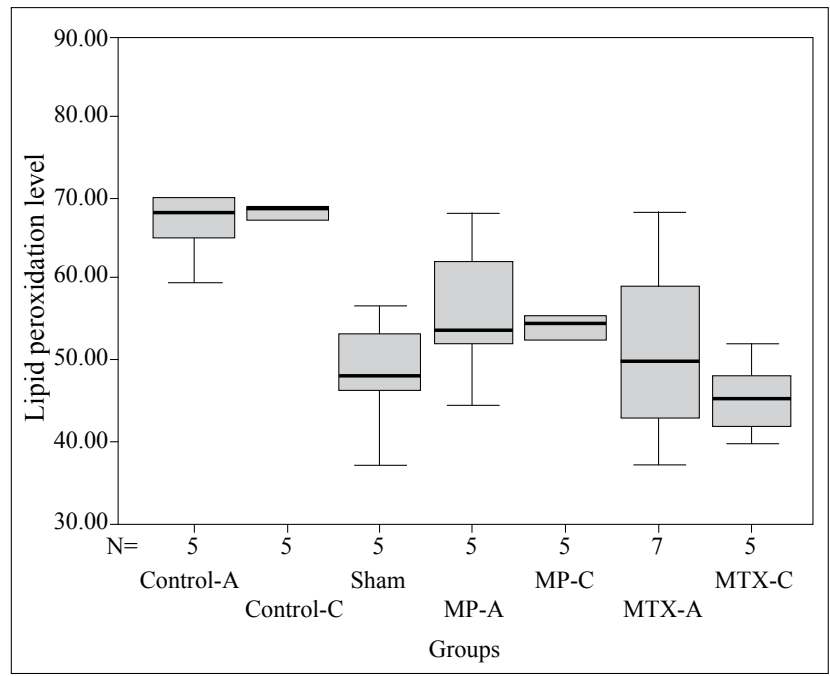

Fig. 4. The mean values of the lipid peroxidation levels in acute and subacute stages of SCI. Each error bar shows minimum and maximum lipid peroxidation levels (MP: Methylprednisolon; MTX: Methotrexate). groups. These results showed that neither experimental material could reduce the histopathological grades in either stage of SCI. Further, it could be presumed that statistical differences were derived from the Sham group values. In the acute stage, mild to moderate neuronal destruction with demyelination and cavity formation was found in all groups except the Sham group. It can be suggested that neither low-dose MTX nor MP could decrease the neural tissue destruction and necrosis in the acute or subacute stages of SCI in rats.

The histopathological observations showed no inflammatory reaction in any specimens of groups in the acute stage of SCI except the Control-A group. This finding may be explained by the potent anti-inflamma-

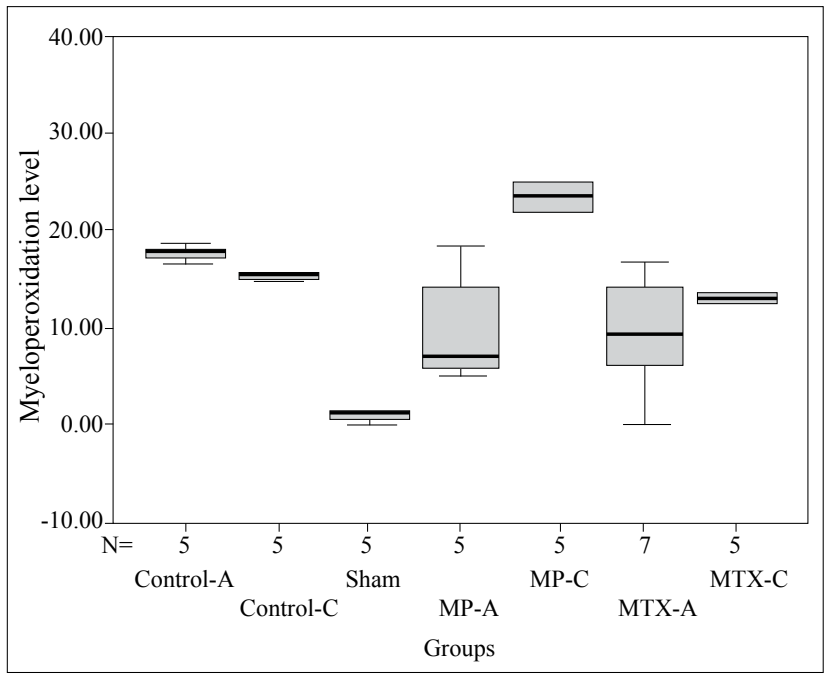

Fig. 5. The mean values of the myeloperoxidation levels in acute and subacute stages of SCI. Each error bar shows minimum and maximum myeloperoxidation levels (MP: Methylprednisolone; MTX: Methotrexate). 
Table 5. Variations in the mean lipid peroxidation and myeloperoxidation levels were statistically significant between all groups

\begin{tabular}{lcc}
\hline & $\mathrm{F}$ & $\mathrm{p}$ \\
\hline Lipid peroxidation & 5.119 & 0.001 \\
Myeloperoxidation & 7.766 & $<0.001$ \\
\hline
\end{tabular}

One-way ANOVA test, $\mathrm{p}<0.05$. F: F test.

tory effect of MP and low-dose MTX, and based on this result, it may be predicted that those experimental materials would cause a reduction in the histopathological grade results. However, the median values of the histopathological grades of the MP-A and MTXA groups were not statistically different from the val- ues of the Control-A group. It can thus be suggested that neither experimental material could decrease or block the inflammatory reaction in the acute stage of SCI in rats. Moreover, moderate inflammatory reaction caused by neutrophils was observed in specimens of the MP-C group, and severe inflammatory reaction developed due to macrophages and histiocytes was observed in the specimens of the MTX-C group. This may mean that MP could not block the neutrophil infiltration into the damaged tissue, and low-dose MTX may enhance the macrophage or histiocyte infiltration into the injured neural tissue in the subacute stage of SCI. Although it could be predicted that these inflammatory reactions would increase the histopathological grades in the MTX-C and MP-C groups, the median values did not support this (Table 1). Even though we

Table 6. Low-dose MTX could decrease lipid peroxidation levels in both stages of spinal cord injury in rats

\begin{tabular}{lcccc}
\hline (I) Group & (J) Group & Mean Difference (I-J) & Standard error & $p$ \\
\hline Sham & Control-A & -20.22 & 5.76 & 0.022 \\
& MP-A & -7.78 & 5.76 & 0.822 \\
& MTX-A & -3.05 & 5.33 & 0.997 \\
Control-A & MP-A & 12.44 & 5.76 & 0.346 \\
& MTX-A & 17.16 & 5.33 & 0.043 \\
MP-A & MTX-A & 4.73 & 5.33 & 0.972 \\
Sham & Control-C & -19.97 & 5.76 & 0.024 \\
& MP-C & -7.11 & 5.76 & 0.875 \\
& MTX-C & 2.88 & 5.76 & 0.999 \\
Control-C & MP-C & 12.86 & 5.76 & 0.308 \\
& MTX-C & 22.85 & 5.76 & 0.007 \\
MP-C & MTX-C & 9.99 & 5.76 & 0.599 \\
\hline
\end{tabular}

One-way ANOVA-Tukey multiple comparison test and Bonferroni multiple comparison test $\mathrm{t}, \mathrm{p}<0.0083$.

MP: Methylprednisolone; MTX: Methotrexate.

Table 7. Low-dose MTX could reduce myeloperoxidation levels in the subacute stage of spinal cord injury in rats

\begin{tabular}{lcccc}
\hline (I) Group & (J) Group & Mean Difference (I-J) & Standard error & $p$ \\
\hline Sham & Control-A & -16.10 & 3.39 & 0.001 \\
& MP-A & -8.60 & 3.39 & 0.181 \\
& MTX-A & -7.94 & 3.14 & 0.184 \\
Control-A & MP-A & 7.50 & 3.39 & 0.318 \\
& MTX-A & 8.17 & 3.14 & 0.160 \\
MP-A & MTX-A & 0.67 & 3.14 & 1.000 \\
Sham & Control-C & -13.73 & 3.39 & 0.005 \\
& MP-C & -20.6 & 3.39 & $<0.001$ \\
& MTX-C & -11.46 & 3.39 & 0.029 \\
Control-C & MP-C & -6.95 & 3.39 & 0.405 \\
& MTX-C & 2.27 & 3.39 & 0.993 \\
MP-C & MTX-C & 9.22 & 3.39 & 0.127 \\
\hline
\end{tabular}

One-way ANOVA-Tukey multiple comparison test and Bonferroni multiple comparison test $\mathrm{t}, \mathrm{p}<0.0083$ MP: Methylprednisolone; MTX: Methotrexate. 
could not demonstrate in the current study the efficacy of these materials in the chronic stage of SCI, it can be said that both experimental materials were inefficient in blocking the inflammatory cell infiltration in the subacute stage of SCI in rats.

\section{Evaluation of the biochemical results}

\section{Evaluation of the LPO levels}

Neutrophils and other phagocytes are major sources of free radicals in the extracellular space in damaged tissue. ${ }^{[1]}$ Additionally, ischemia induced by SCI challenges tissue energy demands and active ion channel functions, and then it may force the neurons to switch from aerobic to anaerobic metabolism. This oxidative stress following SCI may also produce free radicals, which could initiate the LPO activity in the damaged neural tissue. ${ }^{[18]}$

Biochemical evaluation results of the present study demonstrated that neither low-dose MTX nor MP could decrease the LPO levels of the injured neural tissue in the acute stage of SCI. On the other hand, low-dose MTX could decrease the LPO levels to a much greater extent than all other groups, only in the subacute stage. This result may mean that low-dose MTX may be beneficial in reducing the LPO levels and decreasing the free radicals and their destructive effects in the subacute stage of SCI in rats. On the other hand, there was no statistically significant difference between the MTX and MP groups in the subacute stage. It may mean that MP can reduce the LPO levels as much as low-dose MTX. Nevertheless, there was no difference between the Control-C and MP-C groups. Thus, it can be said that low-dose MTX could be much more effective than MP in reducing LPO levels in the subacute stage of SCI.

\section{Evaluation of the MPO levels}

When the neutrophils and other phagocytes reach the injured spinal cord tissue, they produce hypochlorite, a strong oxidant synthesized by the enzyme MPO. ${ }^{[1]}$ MPO is a specific enzyme in the granules of the neutrophils and other phagocytes. MPO activity is correlated with the absolute number of neutrophils and their activations. ${ }^{[14,15]}$ Thus, MPO activity begins to increase gradually during the first 72 hours after SCI, and then returns to uninjured levels in approximately one week after SCI. ${ }^{[1]}$

In the present study, the mean MPO values of the Control, MP and MTX groups demonstrated that neither low-dose MTX nor MP could decrease the MPO activity in either stage of SCI. This may mean that MP and low-dose MTX could not decrease or block the MPO enzyme activity originated from the lysosomes of the inflammatory cells. Histopathological evaluation results also support these findings.

\section{Study limitations}

This study has some pitfalls. First, this study does not contain the behavioral test results or the histopathological and biochemical evaluation results occurring in the long run. As we considered at the onset of the study to investigate the effects of low-dose MTX and MP exclusively in the early stages of SCI in rats, we did not obtain the evaluation results mentioned above because of the short time period. Second, we agree that this study does not contain more specific histopathological analysis for other mechanisms of secondary SCI. Thus, this study should be supported with immunohistochemical and electron microscopic findings that can show ultrastructural details of the inflammatory response, neuronal necrosis and edema in the acute and/or chronic stages of SCI. However, those techniques could not be supported due to inadequacies in our laboratory and equipment. This study should also be supported by using more specific biochemical analyses for other detailed inflammatory pathways of SCI (such as apoptotic pathways, glutathione level, nitrite/nitrate level, and xanthine oxidase activity level measurements). Unfortunately, those tests could not be performed because of some financial and technical restraints. Third, we should evaluate the effects of intrathecal MTX in secondary SCI. However, studies have pointed out that intrathecal MTX may have neurotoxic effects on the spinal cord tissue through development of axonal swelling and loss, demyelination and astrocytosis. ${ }^{[19-22]}$ We thus did not constitute the groups to evaluate the effectiveness of MTX infused via the intrathecal route. Fourth, in this study, we did not constitute a group to examine the combined effects of low-dose MTX and MP on the secondary mechanisms of SCI.

In conclusion, this preliminary study demonstrated that:

1) Neither low-dose MTX nor MP administration could alter the onset or degree of necrosis in the SCI zone in rats.

2) Low-dose MTX could be much more effective than MP in reducing the LPO levels in the subacute stage of SCI in rats.

3) Neither low-dose MTX nor MP could decrease the MPO levels at either stage of SCI.

In conclusion, low-dose MTX was more effective than MP in the prevention of LPO activation only in the subacute stage of SCI, even though histopathological evaluation results and MPO values of the groups did not support this finding in either stage of SCI in rats.

\section{Acknowledgement}

The authors express their gratitude to Mrs. Zer- 
rin Nakip for editing the manuscript and to Mr. Erkan Kaya for his skilled assistance during the study.

Conflict-of-interest issues regarding the authorship or article: None declared.

\section{REFERENCES}

1. Bao F, Chen Y, Dekaban GA, Weaver LC. Early anti-inflammatory treatment reduces lipid peroxidation and protein nitration after spinal cord injury in rats. J Neurochem 2004;88:1335-44.

2. Kaynar MY, Hanci M, Kafadar A, Gümüştaş K, Belce A, Ciplak N. The effect of duration of compression on lipid peroxidation after experimental spinal cord injury. Neurosurg Rev 1998;21:117-20.

3. Cronstein BN, Naime D, Ostad E. The antiinflammatory mechanism of methotrexate. Increased adenosine release at inflamed sites diminishes leukocyte accumulation in an in vivo model of inflammation. J Clin Invest 1993;92:2675-82.

4. Katchamart W, Trudeau J, Phumethum V, Bombardier C. Efficacy and toxicity of methotrexate (MTX) monotherapy versus MTX combination therapy with non-biological disease-modifying antirheumatic drugs in rheumatoid arthritis: a systematic review and meta-analysis. Ann Rheum Dis 2009;68:1105-12.

5. Chan ES, Cronstein BN. Molecular action of methotrexate in inflammatory diseases. Arthritis Res 2002;4:266-73.

6. Montesinos MC, Takedachi M, Thompson LF, Wilder TF, Fernández P, Cronstein BN. The antiinflammatory mechanism of methotrexate depends on extracellular conversion of adenine nucleotides to adenosine by ecto-5'-nucleotidase: findings in a study of ecto-5'-nucleotidase gene-deficient mice. Arthritis Rheum 2007;56:1440-5.

7. Rivlin AS, Tator $\mathrm{CH}$. Effect of duration of acute spinal cord compression in a new acute cord injury model in the rat. Surg Neurol 1978;10:38-43.

8. Black P, Markowitz RS, Cooper V, Mechanic A, Kushner H, Damjanov I, et al. Models of spinal cord injury: Part 1. Static load technique. Neurosurgery 1986;19:752-62.

9. Mihara M, Uchiyama M. Determination of malonaldehyde precursor in tissues by thiobarbituric acid test. Anal Biochem 1978;86:271-8.

10. Ohkawa H, Ohishi N, Yagi K. Assay for lipid peroxides in animal tissues by thiobarbituric acid reaction. Anal Biochem 1979;95:351-8.

11. Demirpençe E, Köksoy C, Kuzu A, Kılınç K. A spectropho- tometric assay for tissue-associated myeloperoxidase activity and its application to intestinal ischemia-reperfusion. Turk J Med Sci 1997;27:197-200.

12. Suzuki K, Ota H, Sasagawa S, Sakatani T, Fujikura T. Assay method for myeloperoxidase in human polymorphonuclear leukocytes. Anal Biochem 1983;132:345-52.

13. Nie NH, Hull CH, Jenkins JG. SPSS: statistical package for social science. New York: McGraw Hill Inc.; 1975.

14. Christie SD, Comeau B, Myers T, Sadi D, Purdy M, Mendez I. Duration of lipid peroxidation after acute spinal cord injury in rats and the effect of methylprednisolone. Neurosurg Focus 2008;25:E5.

15. Mullane KM, Kraemer R, Smith B. Myeloperoxidase activity as a quantitative assessment of neutrophil infiltration into ischemic myocardium. J Pharmacol Methods 1985;14:157-67.

16. Leskovar A, Moriarty LJ, Turek JJ, Schoenlein IA, Borgens RB. The macrophage in acute neural injury: changes in cell numbers over time and levels of cytokine production in mammalian central and peripheral nervous systems. J Exp Biol 2000;203:1783-95.

17. Merola A, O'Brien MF, Castro BA, Smith DA, Eule JM, Lowe TG, et al. Histologic characterization of acute spinal cord injury treated with intravenous methylprednisolone. J Orthop Trauma 2002;16:155-61.

18. Torres S, Salgado-Ceballos H, Torres JL, Orozco-Suarez S, Díaz-Ruíz A, Martínez A, et al. Early metabolic reactivation versus antioxidant therapy after a traumatic spinal cord injury in adult rats. Neuropathology 2010;30:36-43.

19. Gregorios JB, Gregorios AB, Mora J, Marcillo A, Fojaco RM, Green B. Morphologic alterations in rat brain following systemic and intraventricular methotrexate injection: light and electron microscopic studies. J Neuropathol Exp Neurol 1989;48:33-47.

20. Kwong YL, Yeung DY, Chan JC. Intrathecal chemotherapy for hematologic malignancies: drugs and toxicities. Ann Hematol 2009;88:193-201.

21. Mahoney DH Jr, Shuster JJ, Nitschke R, Lauer SJ, Steuber $\mathrm{CP}$, Winick N, et al. Acute neurotoxicity in children with B-precursor acute lymphoid leukemia: an association with intermediate-dose intravenous methotrexate and intrathecal triple therapy--a Pediatric Oncology Group study. J Clin Oncol 1998;16:1712-22.

22. Vezmar S, Becker A, Bode U, Jaehde U. Biochemical and clinical aspects of methotrexate neurotoxicity. Chemotherapy 2003;49:92-104. 